\title{
AUTHOR INDEX Volume 1
}

Alan White, see John Hull

Arlette C. Wilson \& Ronald L.

Clark, Does allowing

alternative hedge designations

affect financial statement

comparability?

Betty J. Simkins, see Raj

Aggarwal

Chris Mallin, see Theresa

Dunne

Christine Helliar, see Theresa

Dunne

David Power, see Theresa

Dunne

Fabrice Rouah, see Masoud

Asgharian

Fernando Diz, see Masoud

Asgharian

Greg N. Gregoriou, see Masoud

Asgharian

Guy Coughlan, Simon Emery

\& Johannes Kolb, Heat ${ }^{T M}$

(hedge effectiveness analysis

toolkit): a consistent

framework for assessing

hedge effectiveness under IAS

39 and FAS 133 from

JPMorgan

In Joon Kim, Suk Joon Byun

\& Sonya Seongyeon Lim,

Valuing and hedging

American options under

time-varying volatility

Ira G. Kawaller \& Walter R.

Teets, Alternative hedge accounting treatments for foreign exchange forwards

James Krochka, see Stewart Karlinsky

Jin E. Zhang, see Jinghong

Shu
$1(2004) 3$

$2(2004) 127$

$1(2004) 61$

2 (2004) 205

$2(2004) 205$

2 (2004) 205

2 (2004) 187

$\mathbf{2}(2004) 187$

$2(2004) 187$

2 (2004) 221

$2(2004) 195$

2 (2004) 139

1 (2004) 111

2 (2004) 171
Jinghong Shu \& Jin E. Zhang,

Pricing SEP 500 index

options under stochastic

volatility with the indirect

inference method

Johannes Kolb, see Guy

Coughlan

John Hull \& Alan White, Accounting for employee stock options: a practical approach to handling the valuation issues

Jongchan Park, The effects of SFAS No. 133 on financial statements in bank holding companies: earnings volatility and equity volatility

2 (2004) 171

2 (2004) 221

$1(2004) 3$

Kean Ow-Yong, see Theresa

Dunne

2 (2004) 151

2 (2004) 205

Ken L. Bechmann \& Peter

Løchte Jørgensen, The value and incentives of

option-based compensation in

Danish listed companies

1 (2004) 91

Lance Moir, see Theresa

Dunne

2 (2004) 205

Lerong He \& Martin J.

Conyon, CEO compensation, incentives, and governance in new enterprise firms

Martin J. Conyon, see Lerong $\mathrm{He}$

$1(2004) 47$

$1(2004) 47$

Masoud Asgharian, Fernando

Diz, Greg N. Gregoriou \&

Fabrice Rouah, The global macro hedge fund cemetery

Peter Løchte Jørgensen, see

Ken L. Bechmann

2 (2004) 187

1 (2004) 91

Raj Aggarwal \& Betty J.

Simkins, Evidence on

voluntary disclosures of 
derivatives usage by large US companies

Richard Gifford, see Steven

Balsam

Ronald L. Clark, see Arlette C. Wilson

Shane A. Johnson \& Yisong S.

Tian, Risk-averse executives, multiple common risks, and the efficiency and incentives of indexed executive stock options

Simon Emery, see Guy Coughlan

Sonya Seongyeon Lim, see In Joon Kim

Steven Balsam \& Richard Gifford, The effect of taxes on the timing of stock option exercise

Steven Todd, see Tom Nohel

$\mathbf{1}(2004) 61$
$\mathbf{1}(2004) 83$
$\mathbf{2}(2004) 127$
$\mathbf{1}(2004) 11$
$\mathbf{2}(2004) 221$
$\mathbf{2}(2004) 195$
$\mathbf{1}(2004) 83$
$\mathbf{1}(2004) 29$

Stewart Karlinsky \& James Krochka, An introduction to US tax aspects of executive/ employee compensation with a stock option focus

1 (2004) 111

Suk Joon Byun, see In Joon Kim

Theresa Dunne, Christine Helliar, David Power, Chris Mallin, Kean Ow-Yong \& Lance Moir, The introduction of derivatives reporting in the $U K$ : a content analysis of FRS 13 disclosures

Tom Nohel \& Steven Todd, Stock options and managerial incentives to invest

Walter R. Teets, see Ira G.

Kawaller

Yisong S. Tian, see Shane A. Johnson
1 (2004) 29

2 (2004) 195

$\mathbf{2}(2004) 139$

1 (2004) 11 